\title{
NON-TRAUMATIC COMA IN CHILDREN: CLINICAL PROFILE AND OUTCOME
}

\author{
Venugopal Suganthi' ${ }^{1}$ Muthusamy Senthil Kumar², Banahatty Raman Sasi Kumar ${ }^{3}$ \\ 1 Professor, Department of Paediatrics, Coimbatore Medical College Hospital, Coimbatore, Tamilnadu. \\ ${ }^{2}$ Associate Professor, Department of Paediatrics, Coimbatore Medical College Hospital, Coimbatore, Tamilnadu. \\ ${ }^{3}$ Assistant Professor, Department of Paediatrics, Coimbatore Medical College Hospital, Coimbatore, Tamilnadu.
}

\section{ABSTRACT}

\section{OBJECTIVE}

To study the aetiology and clinical profile of non-traumatic coma in children and to determine the clinical signs predictive of outcome.

\section{METHODS}

50 cases of non-traumatic coma between 2 months and 12 years were studied. Data collected include temperature, pulse rate, blood pressure, respiratory rate, Glasgow coma scale, papillary reflex, tone and fundus. Data was analysed by Chi-square test and Fisher exact test for differences in proportion of categorical variables between 2 or more groups.

\section{RESULTS}

Aetiology of coma in $58 \%$ of cases was infectious, other causes were status epilepticus (20\%), metabolic (10\%), intoxication $(4 \%)$, intracranial bleed $(2 \%)$ and miscellaneous $(6 \%)$. Among the predictions of mortality - GCS $<8$, abnormal muscle tone and papillary reflex were found to be statistically significant $(\mathrm{p}<0.01)$.

\section{CONCLUSION}

CNS infections were the most common cause of non-traumatic coma in children. Simple clinical signs were good predictors of outcome.

\section{KEYWORDS}

Coma, Children, Non-Traumatic.

HOW TO CITE THIS ARTICLE: Suganthi V, Kumar MS, Kumar BRS. Non-traumatic coma in children: clinical profile and outcome. J. Evolution Med. Dent. Sci. 2016;5(17):867-870, DOI: 10.14260/jemds/2016/200

\section{INTRODUCTION}

Non-traumatic coma is an important source of morbidity and mortality in the paediatric age group. ${ }^{1}$ Accurate diagnosis of aetiology of childhood coma in resource poor countries is complicated by overlap in clinical presentation, limited diagnostic resources, disease endemicity and co-morbidity. ${ }^{2}$ Considerable skill is required to distinguish the group at high risk for further deterioration, potentially leading either to death or severe handicap. This study attempts to identify the common aetiological factors of paediatric comatose patients as well as the predictors of poor outcomes in these patients.

\section{METHODS}

The present observational, retrospective study was conducted at a tertiary care hospital in South India from January 2014 to January 2015. Children of either sex, aged between 2 months and 12 years, admitted with acute alteration of consciousness for more than six hours were the subjects of study. Significant depression of conscious level was defined as a Glasgow coma scale of 12 and below. For children below 5 years of age, the James modification of the Glasgow coma scale was used. Exclusion criteria were coma due to trauma or as part of an anticipated terminal illness. Ethics approved for this study was obtained from the Institutional Ethics Committee.

Financial or Other, Competing Interest: None.

Submission 14-01-2016, Peer Review 10-02-2016,

Acceptance 16-02-2016, Published 29-02-2016.

Corresponding Author:

Dr. Muthusamy Senthil Kumar,

B5-21, TVH Ekanta, GV Residency,

Uppilipalayam Post, Coimbatore-641015,

Tamilnadu.

E-mail: brucemsenthil@rediffmail.com

DOI: $10.14260 /$ jemds/2016/200
Data collected from records include age, sex, other presenting symptoms, diagnosis, clinical features and outcome. Clinical features noted at the time of admission were temperature, heart rate, respiratory rate, systolic blood pressure, Glasgow coma scale, pupillary reflex, tone and fundus.

Data was analysed by Chi Square test and Fisher's exact test to test for differences in proportions of categorical variables between two or more groups. The tests were performed at $5 \%$ significance level.

\section{RESULTS}

A total of 50 children had been admitted with non-traumatic coma. Out of these 50 cases, $10 \%$ belonged to the age group 2 12 months; $30 \% 1$ to 5 years and $60 \% 5$ to 12 years. There was a variation in age dependent incidence with an increased incidence in 5 to 12 year age group. Proportion of male and females were $40.34 \%$ and $59.66 \%$, respectively (Table 1 ). The data related to presentation from 50 records were analysed. The presenting symptoms were convulsions (35 cases), fever (34), headache (26), vomiting (23), cough (5), fast breathing (4), abdominal pain (4), diarrhea (2), visual symptomblindness ( 1 case). Most of the children presented with more than one symptom. Convulsions $(35,90 \%)$ and fever $(34,68 \%)$ were the most common symptoms.

\footnotetext{
Aetiology

Infections - were the predominant cause of non-traumatic coma, accounting for $58 \%$ of cases (Table 2). Acute bacterial meningitis was the most common cause followed by tuberculous meningitis, viral encephalitis, septicemia and cerebral malaria. Among CNS infections, $77 \%$ were in the age group of 5 to 12 years.
} 
There were 8 children with status epilepticus, of which $88 \%$ were in the 5 to 12 years age group. Febrile status was seen in 2 cases and both belonged to 1 to 5 years age group; 2 children presented with intoxication - one organophosphorus poisoning and another Neem oil poisoning. Both were 12 months - 59 months age group. Coma of accidental cause was identified in 1 case and it was due to near drowning. The child was $1-1 / 2$ years old.

\section{Metabolic}

Diabetic Ketoacidosis (DKA) was the aetiology in 3 cases. The episode of DKA was the first presentation in 2 children. They belonged to 5 o 12 years age group. There was 1 child, 8 weeks old, diagnosed to have medium chain Acyl dehydrogenase deficiency. The aetiology was hepatic encephalopathy in 1 child, who was 8 years old and presented with low-grade fever and acute abdominal pain.

\section{Other Causes}

There was 1 child, 4 years who had Intracranial hemorrhage due to acute Idiopathic Thrombocytopenic Purpura. The aetiology was posterior cerebral artery stroke in a 12 years old child, who presented with blindness 3 days prior to the onset of alteration in consciousness. Acute disseminated encephalomyelitis was identified as the cause in a 9 years old child.

\section{Mortality}

Among the 50 children experiencing non-traumatic coma, there were 8 deaths (16\%). Regarding the outcome according to aetiology (Table 2), out of 7 children admitted with viral encephalitis, 2 expired. These children had diffuse cerebral edema and intracranial hypertension, 2 children were admitted with sepsis of which a 4-month-old infant had failure to thrive, faulty child rearing practices, bronchopneumonia and succumbed. In 2 children the aetiology was intoxication, 1 was organophosphorus poisoning, the other was a 2-year-old child with neem oil poisoning. The child with neem oil poisoning succumbed, had intractable seizures and pulmonary edema. There was a 1-1/2-year-old child, admitted with drowning, treated in a private hospital for 9 days and referred here in altered sensorium and respiratory failure. This child expired. A 6-week-old child was diagnosed as Medium chain acyl dehydrogenase deficiency by Tandem mass spectrometry at 4 weeks of age for developmental delay and seizers.

This child was admitted at 8 weeks of age with bronchopneumonia, sepsis and seizures and expired after 10 days of hospital stay. An 8-year-old child was admitted for lowgrade fever, abdominal pain 2 days, shortly after admission developed increased severity of abdominal pain, altered sensorium and posturing. His serum bilirubin and liver enzymes were grossly elevated and he succumbed in few hours. A 12-year-old girl was admitted with a history of decreased visual acuity for 3 days and was followed by altered sensorium. She had clinical features of increased intracranial pressure. Her CT angiography showed a posterior cerebral artery stroke with diffuse cerebral edema and she succumbed.

The predictors of mortality were analysed (Table 3). Out of 24 children with GCS $<8,8$ had died. Among 11 children with nonreactive pupils, 5 expired and out of 9 children with tone abnormalities, 7 had died. The variables GCS $<8$, pupillary reflex and tone were found to be statistically significant ( $p$ $<0.001$ ). Other variables like temperature on admission, heart rate on admission, respiratory rate on admission, systolic blood pressure and papilledema were not statically significant.

\begin{tabular}{|c|c|c|c|}
\hline \multirow{2}{*}{ Age } & M & F & \multirow{2}{*}{ Total } \\
\cline { 2 - 4 } & 2 & 3 & 5 \\
\hline $2-12$ months & 7 & 8 & 15 \\
\hline $13-59$ months & 13 & 17 & 30 \\
\hline 60 months -12 years & $\mathbf{2 2}$ & $\mathbf{2 8}$ & $\mathbf{5 0}$ \\
\hline Total & \multicolumn{2}{|c|}{ Table 1: Age and Sex Distribution } \\
\hline
\end{tabular}

\begin{tabular}{|c|c|c|c|}
\hline Aetiology & $\begin{array}{c}\text { Total No. } \\
\text { of Cases }\end{array}$ & $\begin{array}{c}\text { No. of } \\
\text { Cases Survived }\end{array}$ & $\begin{array}{c}\text { No. of } \\
\text { Cases Death }\end{array}$ \\
\hline Acute bacterial meningitis & 11 & 11 & - \\
Tuberculous Meningitis & 8 & 8 & - \\
Viral encephalitis & 7 & 5 & 1 \\
Sepsis & 2 & 1 & - \\
Cerebral malaria & 1 & 1 & - \\
Status epilepticus & 8 & 8 & - \\
Febrile status & 2 & 2 & 1 \\
Intoxication & 2 & 1 & - \\
Drowning & 1 & - & 1 \\
Diabetic ketoacidosis & 3 & 3 & - \\
MCAD deficiency & 1 & - & 1 \\
Hepatic encephalopathy & 1 & 1 & - \\
Intracranial hemorrhage & 1 & - & $\mathbf{8}$ \\
PCA stroke & 1 & 1 & $\mathbf{4 2}$ \\
\hline ADEM & $\mathbf{5 0}$ & \\
\hline \multicolumn{2}{|c|}{ Total } \\
\hline
\end{tabular}




\begin{tabular}{|c|c|c|c|c|c|c|c|}
\hline Variables & & $\begin{array}{c}\text { No. of } \\
\text { Patients }\end{array}$ & Survived & Expired & Chi-sq value & P Value & Result \\
\hline $\begin{array}{l}\text { Temperature } \\
\text { on admission }\end{array}$ & $\begin{array}{c}\text { Afebrile } \\
\text { Hypothermic } \\
>100^{\circ} \mathrm{F} \\
>104^{\circ} \mathrm{F}\end{array}$ & $\begin{array}{c}11 \\
1 \\
26 \\
12 \\
\end{array}$ & $\begin{array}{c}8 \\
0 \\
24 \\
10 \\
\end{array}$ & $\begin{array}{l}3 \\
1 \\
2 \\
2 \\
\end{array}$ & 7.629 & 0.054 & NS \\
\hline $\begin{array}{l}\text { Heart Rate on } \\
\text { admission }\end{array}$ & $\begin{array}{c}\text { Normal } \\
\text { Bradycardia } \\
\text { Tachycardia }\end{array}$ & $\begin{array}{c}15 \\
5 \\
30 \\
\end{array}$ & $\begin{array}{c}14 \\
3 \\
25\end{array}$ & $\begin{array}{l}1 \\
2 \\
5\end{array}$ & 3.617 & 0.306 & NS \\
\hline $\begin{array}{l}\text { Respiratory } \\
\text { rate } \\
\text { on admission }\end{array}$ & $\begin{array}{c}\text { Normal } \\
\text { Bradypnea } \\
\text { Tachypnea }\end{array}$ & $\begin{array}{c}37 \\
4 \\
9 \\
\end{array}$ & $\begin{array}{c}33 \\
2 \\
7 \\
\end{array}$ & $\begin{array}{l}4 \\
2 \\
2 \\
\end{array}$ & 4.441 & 0.349 & NS \\
\hline Systolic BP & $\begin{array}{c}\text { Normal } \\
\text { Low } \\
\text { High } \\
\end{array}$ & $\begin{array}{c}44 \\
3 \\
3 \\
\end{array}$ & $\begin{array}{c}38 \\
1 \\
3 \\
\end{array}$ & $\begin{array}{l}6 \\
2 \\
- \\
\end{array}$ & 0.571 & 0.752 & NS \\
\hline GCS & $\begin{array}{c}3 \\
3-8 \\
>8 \\
\end{array}$ & $\begin{array}{c}7 \\
17 \\
26 \\
\end{array}$ & $\begin{array}{c}1 \\
15 \\
26 \\
\end{array}$ & $\begin{array}{l}6 \\
2 \\
- \\
\end{array}$ & 24.246 & 0.00 & $* *$ \\
\hline $\begin{array}{l}\text { Pupillary } \\
\text { reflex }\end{array}$ & $\begin{array}{c}\text { Reacting } \\
\text { Nonreacting } \\
\end{array}$ & $\begin{array}{l}39 \\
11 \\
\end{array}$ & $\begin{array}{c}36 \\
6 \\
\end{array}$ & $\begin{array}{l}3 \\
5 \\
\end{array}$ & $\begin{array}{c}\text { Fisher exact } \\
\text { test }\end{array}$ & 0.00 & $* *$ \\
\hline Tone & $\begin{array}{c}\text { Normal } \\
\text { Hypertonia } \\
\text { Hypotonia }\end{array}$ & $\begin{array}{c}41 \\
4 \\
5 \\
\end{array}$ & $\begin{array}{c}39 \\
1 \\
2 \\
\end{array}$ & $\begin{array}{l}2 \\
3 \\
3 \\
\end{array}$ & 21.336 & 0.0002 & $* *$ \\
\hline Fundus & $\begin{array}{c}\text { Normal } \\
\text { Papilledema }\end{array}$ & $\begin{array}{c}47 \\
3 \\
\end{array}$ & $\begin{array}{c}40 \\
2 \\
\end{array}$ & $\begin{array}{l}7 \\
1 \\
\end{array}$ & $\begin{array}{c}\text { Fisher exact } \\
\text { test }\end{array}$ & 0.529 & NS \\
\hline
\end{tabular}

* - Significant at $1 \%$ level NS - Not significant

\section{DISCUSSION}

In our study, out of 50 children maximum cases (60\%) were in the age group of 5 to 12 years. A recent study from India. ${ }^{3}$ showed the preponderance in 3-6 years age group. The causes of non-traumatic coma vary by country, season and period of data collection. Seshia SS, et al. ${ }^{4}$ Bansal A, et al. ${ }^{5}$ in their study found CNS infections contributed to $60 \%$ of aetiology of nontraumatic coma in 100 children. The present study is consistent with this finding. In $58 \%$ of the cases, CNS infections were the cause, most notably Acute Pyogenic Meningitis $(\mathrm{n}=11)$, Tuberculous Meningitis $(\mathrm{n}=8)$, Viral Encephalitis $(n=7)$ and cerebral malaria $(n=1)$. In a study by Ahmed $S$, et al. ${ }^{6}$ out of 100 children with NTC, $66 \%$ had infectious aetiologies. Jindal A, et al. ${ }^{7}$ also reported that CNS infections were the most common cause of NTC in children. In a study by Fouad H, et al. ${ }^{8}$ in 100 consecutive paediatric NTC cases, the most common aetiology was metabolic (33\%) followed by CNS (28\%) infections. In our study the mortality was $16 \%$, whereas the mortality was around $25 \%$ in studies from other countries. ${ }^{9,10}$

In this study, the mortality was found in viral encephalitis ( 2 out of 7 cases), one each in sepsis, drowning, poisoning, IEM, hepatic encephalopathy and stroke. In a study by Sinelair JR, et al. ${ }^{11}$ the aetiology was also important in determining outcome. Hospital morality in their study was lowest in patients with cerebral malaria, organophosphorus poisoning. Matuja WB, et al. ${ }^{10}$ also reported that the cause of coma was an important indicator of prognosis. In their study, good recovery was achieved with cerebral malaria, diabetic ketoacidosis, acute bacterial meningitis and drug overdose.

Among the patient's vital signs recorded at the time of admission, temperature, heart rate, respirators rate, systolic blood pressure did not correlate with poor outcome. Other investigators.(11,12) have found hypotension, abnormal respiratory pattern at admission correlated significantly with mortality. Clinical features which showed increased association with mortality include GCS $<8$, non-reactive pupils and abnormalities in tone $(\mathrm{P}<.01)$. The GCS is a standardized system developed initially in traumatic coma to assess the degree of coma and to identify the seriousness of brain injury in relation to outcome. 100 studies in NTC have indicated that the mortality is significantly high when the GCS is less than 8.(13) P. C. Nayanaprabha, et al.(14) have found that the mortality was higher when the ocular and verbal response score is

$<2$, motor response 1 and brainstem score $<1$. The use of brainstem reflexes has increased the prediction of mortality in NTC.(15) Periodical evaluation of brainstem reflexes is important to recognize the intracranial hypertension and herniation syndrome.(16)

The examination of brain stem comprises of respiratory pattern, pupil size, response to light, oculocephalic reflexes, tone and posture. The stage of diencephalic herniation may be mimicked by drugs, toxins, metabolic abnormalities as well as intra- and post-ictal states. If children are seen with even some of the signs of diencephalic or uncal or midbrain/upper pontine phases of central herniation, emergency management of presumed raised ICP is mandatory. Recovery is extremely unlikely if the patient had reached the lower pontine or medullary stage. In our study, out of 24 patients with increased intracranial pressure 4 succumbed.

Raised intracranial pressure exists in varying degrees of severity in all encephalopathies of non-traumatic aetiology (Infectious and non-infectious causes). ${ }^{17}$ Signs that are almost always present with increased intracranial pressure and herniation are depressed level of consciousness, hypertension with or without heart rate changes- usually bradycardia, sometimes tachycardia. ${ }^{18}$

In our study, we have found that GCS $<8$, non-reactive pupillary reflex and tone abnormalities were significant predictors of mortality. Presence of papilledema did not correlate with outcome. The limitation of this study is that it is an observational study with a small sample size done in a retrospective manner. But it has provided an understanding of 
the aetiology and predictors of outcome of non-traumatic coma, which can influence the development of better management strategies.

\section{REFERENCES}

1. Wong CP, Forsyth RJ, Kelly TP, et al. Incidence, aetiology and outcome of non-traumatic coma: a population based study. Arch Dis Child 2001;S4:193-199.

2. Gwer S, Chacha C, Newton CR, et al. Childhood acute nontraumatic coma: aetiology and challenges in management in resource-poor countries of Africa and Asia. Paediatr Int Child Health 2013 Aug;33(3):129-138. Doi: 10. 1179/2046905513 Y. 000000068.

3. Bokade CM, Gulhare RR, Thakre SB. Acute febrile encephalopathy in children and predictors of mortality. J Chin Diagn Res 2014 Aug;8(8):PC 09-PC 11.

4. Seshia SS, Bingham WT, Kirkham FJ, et al. Non-traumatic coma in children and adolescents: diagnosis and management. Neurol Clin 2011 Nov;29(4):1007-43.

5. Bansal A, Singhi SC, Singhi PD, et al. Non-traumatic coma. Indian J Paediatr 2005 Jun;72(6):467-73.

6. Ahmed S, Ejaz K, Shamion MS, et al. Non-traumatic coma in paediatric patients: aetiology and predictors of outcome. J Pak Med Assoc 2011 Jul;61(7):671-5.

7. Jindal A, Singhi SC, Singhi P. Non-traumatic coma and altered mental status. Indian J Pediatr 2012 Mar; 79(3):367-75.

8. Fouad H, Haron M, Halawa EF, et al. Non-traumatic coma in a tertiary paediatric emergency department in Egypt: aetiology and outcome. J Child Neurol 2011 Feb;26(2): $136-41$
9. Vijayakumar K, Knight R, Prabhakar P, et al. Neurological outcome in children with non-traumatic coma admitted to a regional paediatric intensive care unit. Arch Dis child 2003;88:A30-2.

10. Matuja WB, Matekere NJ. Causes and early prognosis of non-traumatic coma in Tanzania, Muhimbili Medical Centre experience. Trop Geogr MCA 1987;39:330-5.

11. Ikhlas Ahmad, Kaisar Ahmed, Imran Ahmad Gattoo, et al. Non-traumatic coma in children: a prospective observational study. Int J Contemp Pediatr 2015; 2(2): 77-84.

12. Johnston B, Seshia SS. Prediction of outcome in nontraumatic coma in childhood. Acta Neurol Scand 1984;69:417-27.

13. Sacco RL, Van Gool R, Mohr JP. Non-traumatic coma. Glasgow coma score and coma aetiology as prediction of outcome. Arch Neurol 1994;47:1181-84.

14. Nayana Prabha PC, Nailini P, Tiroumouronganeserane V. Role of Glasgow coma scale in paediatric non-traumatic coma. Indian Pediatr 2003 Jul;40(7):620-5.

15. Levy DE, Bates D, Caronna JJ, et al. Prognosis in nontraumatic coma. Ann Intera Med 1981;94:293-301.

16. Kirkham FJ. Non-traumatic coma in children. Arch Dis child 2001;85:303-312.

17. Santhanam I. Approach to decreased level of consciousness, paediatric emergency medicine course $2^{\text {nd }}$ edn. 2013;187-195.

18. Ranjit S. Intracranial hypertension: pathophysiology and approach to therapy. Indian Journal of Practical Paediatrics 2014;16(1):23-31. 